\title{
Certifications for Sustainable Buildings in Brazil: Comparative Study on Quantity of Certifications
}

\author{
Marcelo de Mattos Bezerra ${ }^{1, a}$ and Alfredo Jefferson de Oliveira ${ }^{2}$ \\ ${ }^{1}$ PUC-Rio - Pontifícia Universidade Católica do Rio de Janeiro [Pontifical Catholic University of Rio de Janeiro], Architecture and \\ Urbanism Department, Rua Marquês de São Vicente, 225 - Edifício Cardeal Leme - Sala 327 \\ ${ }^{2}$ PUC-Rio - Pontifícia Universidade Católica do Rio de Janeiro, Arts and Design Department, Rua Marquês de São Vicente, 225 - \\ Casa das Artes
}

\begin{abstract}
Certifications for sustainable buildings have been developed in various countries on the initiative of organizations with the participation of various actors from the construction sector. They are certifications that aim for sustainability with a focus on the better management of resources, the more rational use of space, the quality of the constructed space, the improvement of construction processes, among other things. This study covers four ventures adopted or created in Brazil: two certifications of foreign origin, AQUA-HQE and LEED, with an energy efficiency label, PBE Edifica (Programa Brasileiro de Etiquetagem Edifica [Brazilian Labelling Programme Building]), and a seal, Selo Casa Azul [Blue House Seal], being the main movements for certifications. This article, based on previous research, presents a survey on the quantities of certifications and on the project areas of the four certifications mentioned above. The data obtained from the entities responsible for the creation and dissemination of the four certificates was collected and organized, analysed and compared in order to reach conclusions afterwards. Two types of projects were considered: Residential and Non-Residential. With Residential projects, the focus was on multi-family buildings and with Non-Residential projects all types of buildings, even based on the differences in classifications in each one of the ventures. Another classification was the separation, with respect to Non-Residential certifications, of new buildings and in large-scale renovations of buildings in operation. Another surveyed and quantified datum was housing units in multi-family buildings
\end{abstract}

Keywords. Sustainability, Sustainable Construction, Sustainable Building Certification.

\section{Introduction}

Sustainable Construction has been encouraged in various countries. Certifications, seals and labels consist of a set of categories and criteria with points. Many items included in certifications originate from legislation from cities and/or countries and points are awarded upon surpassing the respective requirements. The internationalization of certifications, with the adoption of common rules for countries with different realities, requires special attention and is the target of criticism.

Certifications are tools for evaluating the sustainability of buildings with environmental, social and economic requirements. They can be very useful for designers and developers and are a guide for alternatives with less of an impact on the environment (LAMBERTS, TRIANA, FOSSATI, BATISTA 2007).

Generally speaking, in Brazil additional costs are still considered the main barrier for adopting sustainability and, as a consequence, certifications (LEITE JÚNIOR 2013).

Find below the four main certifications adopted in Brazil with some of the main characteristics:
- AQUA-HQE: In France, HQE - Haute Qualité Environnementale - Process and in Brazil, adapted by the Vanzolini Foundation, of the Polytechnic School of USP (University of São Paulo), AQUA-HQE - High Environmental Quality - with a large percentage for residential buildings.

- LEED - Leadership in Energy and Environmental Design: Certification developed in the United States by USGBC - United States Green Building Council. In Brazil, it predominates in new corporate buildings and renovations.

- PBE Edifica - Brazil: Label for energy efficiency with bonuses for solutions relating, for example, to the reduction of water consumption. Available for Commercial, Service-Related, Public and Residential Buildings. In 2014, the Selo Procel Edificações [Procel Buildings Seal] was launched.

- Selo Casa Azul - Brazil: Launched by Caixa Econômica Federal in 2010, it is intended for residential developments financed by the bank (BEZERRA; JEFFERSON, 2015).

HQE and LEED are members of the World GBC World Green Building Council. In some countries, there are governmental incentives or regulations, such as in

\footnotetext{
${ }^{\mathrm{a}}$ Corresponding author: mmb@puc-rio.br
} 
the USA, where Washington State requires public buildings to have LEED in the Gold category (LAMBERTS, TRIANA, FOSSATI, BATISTA 2007).

In citations, the term, Certifications, will be adopted to cover Certifications, Seals and Labels.

This article presents quantitative data on residential and non-residential buildings, new and existing constructions and housing units. In the second part some comparisons are discussed, with the respective analyses. The conclusion features the final considerations and suggestions.

\section{Data Presentation}

Below one may find the presentation of quantitative data on certification in Brazil. The information was obtained by consulting the entities responsible for the certifications, labels and seals in Brazil by e-mail and telephone calls. The references for the depicted information are mentioned in References at the end of the article.

For residential certifications, multi-family residential buildings were considered. Single-family residences were not accounted for.

For the quantities, differences between certifications in progress and concluded certifications were not considered.

\subsection{Multi-Family Residential and Non- Residential Buildings}

In Brazil, AQUA-HQE (COSTA 2017) and LEED (CARVALHO 2017) have been used in different and specific ways, since while the first one separates commercial buildings from residential buildings, the second one only features commercial buildings among the certified projects.

For grouping the types of projects in the tables, the criteria used by AQUA-HQE of "residential" and "nonresidential" buildings was adopted. The neighbourhood certifications of LEED and AQUA-HQE certifications were excluded. Selo Casa Azul (SERNA, MOTTA 2017) only applies to residential developments.

For the quantity of HQE-AQUA certifications, the number of developments was considered.

Table 1 Quantities of Multi-Family Residential and NonResidential Certifications.

\begin{tabular}{|c|c|c|c|c|c|}
\hline & $\begin{array}{c}\text { HQE- } \\
\text { AQUA }\end{array}$ & LEED & $\begin{array}{c}\text { Selo } \\
\text { Casa } \\
\text { Azul }\end{array}$ & $\begin{array}{c}\text { PBE } \\
\text { Edifica }\end{array}$ & $\begin{array}{c}\text { Overall } \\
\text { Totals }\end{array}$ \\
\hline $\begin{array}{c}\text { Non- } \\
\text { Residential }\end{array}$ & 128 & 398 & - & 193 & 719 \\
\hline $\begin{array}{c}\text { Multi-Family } \\
\text { Residential }\end{array}$ & 118 & 2 & 21 & 44 & 185 \\
\hline Subtotals & 246 & 400 & 21 & 237 & 904 \\
\hline
\end{tabular}

The table below depicts the quantities in area of the developments. For Selo Casa Azul, the areas were estimated based on the quantities and types of housing units on the developments mentioned at the link provided by Caixa Econômica Federal. With respect to PBE Edifica (ELETROBRAS 2017), the data on the areas of the projects is also not available and it was also not provided during contact made.

Table 2 Areas of Multi-Family Residential and NonResidential Certifications $\left(1,000 \mathrm{~m}^{2}\right)$.

\begin{tabular}{|c|c|c|c|c|}
\hline & $\begin{array}{c}\text { HQE- } \\
\text { AQUA }\end{array}$ & LEED & $\begin{array}{c}\text { Selo Casa } \\
\text { Azul }\end{array}$ & $\begin{array}{c}\text { Overall } \\
\text { Totals }\end{array}$ \\
\hline $\begin{array}{c}\text { Non- } \\
\text { Residential }\end{array}$ & 4,184 & 7,800 & - & 11,984 \\
\hline $\begin{array}{c}\text { Multi-Family } \\
\text { Residential }\end{array}$ & 3,534 & 20 & 1,467 & 5,021 \\
\hline Subtotals & 7,718 & 7,820 & 1,467 & 17,005 \\
\hline
\end{tabular}

\subsection{New Non-Residential Buildings / Large-Scale Renovations and In Operation}

There is no clear criterion for differentiating between certifications for new and existing buildings, but rather specific certifications for buildings in operation. For the time being, this certification has only been applied to Non-Residential buildings. Based on the foregoing, certifications for New Non-Residential Buildings are grouped with Large-Scale Renovations. In this item of the article, only the Non-Residential AQUA-HQE (COSTA 2017) and LEED (CARVALHO 2017) certifications were analysed.

Table 3 Quantities of Certifications for New Non-Residential Buildings / Large-Scale Renovations and Buildings In Operation.

\begin{tabular}{|c|c|c|c|}
\hline & HQE-AQUA & LEED & Overall Totals \\
\hline $\begin{array}{c}\text { New / Large- } \\
\text { Scale } \\
\text { Renovations }\end{array}$ & 84 & 368 & 452 \\
\hline In Operation & 14 & 30 & 44 \\
\hline Subtotals & 98 & 398 & 496 \\
\hline
\end{tabular}

The table below depicts the quantities in area of the certified developments.

Table 4 Areas of Certifications for New Non-Residential Buildings / Large-Scale Renovations and Buildings in Operation $(1,000 \mathrm{~m} 2)$.

\begin{tabular}{|c|c|c|c|}
\hline & HQE-AQUA & LEED & Overall Totals \\
\hline $\begin{array}{c}\text { New / Large- } \\
\text { Scale } \\
\text { Renovations }\end{array}$ & 3,525 & 7,168 & 10,693 \\
\hline In Operation & 248 & 652 & 900 \\
\hline Subtotals & 3,773 & 7,820 & 11,593 \\
\hline
\end{tabular}




\subsection{Housing Units in Multi-Family Residential Buildings}

The quantity of Housing Units in Multi-Family Residential buildings was surveyed, with data obtained and supplied for the four research certifications.

Table 5 Quantities of Housing Units (HUs) in Certified MultiFamily Residential buildings.

\begin{tabular}{|c|c|c|c|c|c|}
\hline & $\begin{array}{c}\text { HQE } \\
\text { AQUA }\end{array}$ & $\begin{array}{c}\text { Referen } \\
\text { tial } \\
\text { GBC } \\
\text { House }\end{array}$ & $\begin{array}{c}\text { Selo } \\
\text { Casa } \\
\text { Azul }\end{array}$ & $\begin{array}{c}\text { PBE } \\
\text { Edifica }\end{array}$ & $\begin{array}{c}\text { Overall } \\
\text { Totals }\end{array}$ \\
\hline $\begin{array}{c}\text { Multi- } \\
\text { family } \\
\text { HUs }\end{array}$ & 47,986 & $66^{*}$ & 8,343 & 2,372 & 58,703 \\
\hline
\end{tabular}

With respect to LEED (CARVALHO 2017), the HU quantity was included with Referential House, created in Brazil by GBC Brazil.

\section{Analyses}

The LEED certification leads in the quantity of NonResidential certifications in Brazil with more than 55\% of total projects, while AQUA-HQE has more than $81 \%$ of Residential buildings. Comparing the project types, Non-Residential certifications predominate, at almost $80 \%$.

Figure 1 Graph on Quantities of Certifications for MultiFamily Residential and Non-Residential buildings.

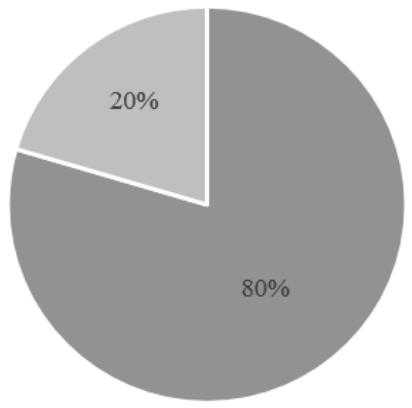

Non-Residential

Multi-Family Residential

Figure 2 Graph on Areas of Certifications for Residential and Non-Residential buildings.

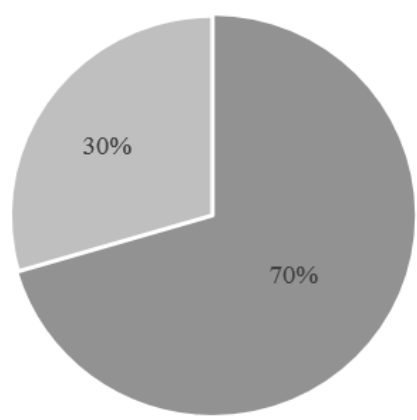

Non-Residential

Multi-Family Residential
Due to the failure to provide data relating to the areas of PBE Edifica labels, it was not feasible to compare all the certifications. In any case, one may find depicted below a table with the average areas of each one of the certifications as to the two types:

Table 6 Average Areas of Multi-Family Residential and NonResidential Certifications $\left(\mathrm{m}^{2}\right)$

\begin{tabular}{|c|c|c|c|c|}
\hline & $\begin{array}{c}\text { HQE- } \\
\text { AQUA }\end{array}$ & LEED & $\begin{array}{c}\text { Selo } \\
\text { Casa } \\
\text { Azul }\end{array}$ & $\begin{array}{c}\text { Average } \\
\text { Areas }\end{array}$ \\
\hline $\begin{array}{c}\text { Non- } \\
\text { Residential }\end{array}$ & 32,687 & 19,597 & - & 11,984 \\
\hline $\begin{array}{c}\text { Multi-Family } \\
\text { Residential }\end{array}$ & 29,949 & 10,000 & 69,857 & 5,021 \\
\hline
\end{tabular}

Table 6 demonstrates that the AQUA-HQE-certified Residential projects have larger areas than LEED in the two types, while Selo Casa Azul exceeds both of them. A point that can explain this is that the AQUA-HQE certification adopts developments and not buildings as the basis for quantities.

Table 3 Quantities of Certifications for New Non-Residential Buildings / Large-Scale Renovations and Buildings In Operation

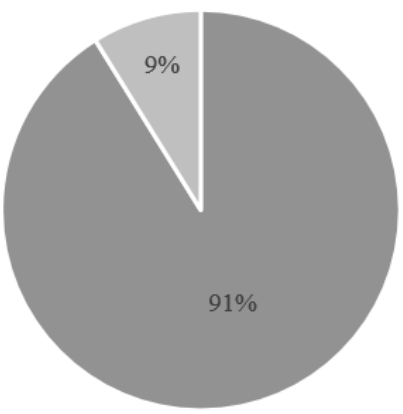

New Buildings / Large-Scale

In Operation

Certifications for New buildings / Large-Scale Renovations are the overwhelming majority with approximately $92 \%$ of the certifications, while certifications for buildings In Operation correspond to $8 \%$ of the total. These percentages practically repeat themselves in the proportion of areas among the totals of certifications' areas.

Figure 4 Graph of Areas of Certifications for New NonResidential Buildings / Large-Scale Renovations and Buildings In Operation

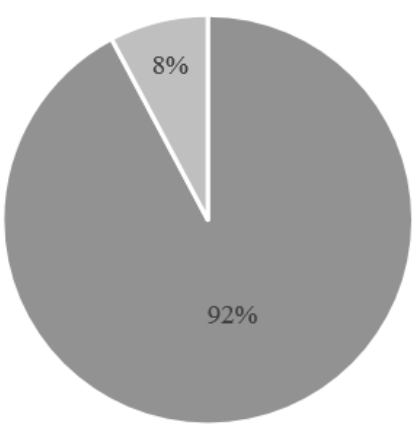


AQUA-HQE and LEED certifications have different percentages in the proportion of certifications of Buildings In Operation with almost $17 \%$ (14 out of 84 ) for the former and a little more than $8 \%$ for the latter.

Figure 4 Graph on Housing Units in Multi-Family Residential Buildings

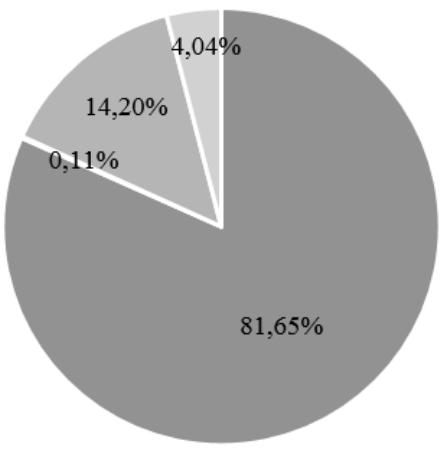

HQE AQUA

Selo Casa Azul

PBE Edifica

Referential GBC House

With respect to Housing Units in Multi-Family Residential Buildings, it is evident that AQUA-HQE certification overwhelmingly holds the leadership with more than $81 \%$ of adoption of total certified units.

\section{Final Considerations}

This article presents the current scenario of certifications in relation to the quantity of certifications and certified areas.

It is evident that certifications in the Non-Residential sector predominate. One of the reasons may be that this category of buildings has, in many cases, a sole owner, which facilitates the making of decisions towards sustainability, which is easily supported by savings obtained, company missions and marketing.

The Residential sector still seems to require foreseeability and greater rigour in the control of accounts, which even in some cases is still not a prerequisite of users, but rather a necessary step for the future of our cities.

Comparing the data supplied by IBGE dated 2010, when there were almost 6.1 million apartments in Brazil, we discovered that fewer than $1 \%$ of the housing units of this type are certified. The trend is for this percentage to be smaller currently due to the quantity of apartments having increased between 2010 and 2017 and to the quantity of certified HUs being a current figure.

The quantity of certifications, even without data on the total buildings delivered over the years in which certifications were introduced in Brazil, is still below the quantity that would be necessary for an actual and real improvement in our cities.

As in conclusions by other studies, it seems to us that the participation of governments will be fundamental. With incentives and requirements to adopt solutions including sustainability, as a consequence, certifications will be made viable.

The next steps by research will be the betterment of data relating to the areas of certifications, the understanding of savings obtained by certified buildings and understanding on introduction in legislation.

\section{References}

BEZERRA M. M.; OLIVEIRA A. J.. QUALIFICAÇÃO QUALIVERDE, A Legislação para Edifícios Sustentáveis do Rio de Janeiro e Análise Comparativa com Certificações [QUALIVERDE QUALIFICATION, Legislation for Sustainable Buildings in Rio de Janeiro and Comparative Analysis with Certifications]. 5th Sustainable Design Symposium. PUC-Rio: Rio de Janeiro, 2015.

CARVALHO, Agatha C. GBC Brazil. Electronic publication [personal message]. Messages received by $<$ mmb@puc-rio.br > on Feb. 18 and Mar. 14. 2017.

COSTA, Leonardo. Vanzolini Foundation. Electronic publication [personal message]. Messages received by $<\mathrm{mmb} @$ puc-rio.br $>$ on Feb. 10 and 21. 2017.

ELETROBRAS. Eletrobras Procel Edifica Team. Electronic publication [personal message]. Messages received by $<$ mmb@puc-rio.br $>$ on Feb. 10 and 14 and Mar. 14. 2017.

IBGE. Tipo de domicílio - casa, apartamento, cômodo [Type of domicile - house, apartment, room]. Séries Estatísticas e Séries Históricas [Statistical Series and Historical Series]. Brazil. Available at: $<\mathrm{http} / / /$ seriesestatisticas.ibge.gov.br/series.aspx?vcodigo $=$ PD206> $>$. Accessed on: Mar. 102017.

LAMBERTS, Roberto; TRIANA, Ma. Andrea; FOSSATI, Michele; BATISTA, Juliana O. Sustentabilidade nas edificações: contexto internacional e algumas referências brasileiras na área [Sustainability of buildings: international contexts and some Brazilian references in the area]. Laboratory on Energy Efficiency in Civil Engineering Buildings - UFSC (CONTINUAR)

LEITE JÚNIOR, Hamilton F. Sustentabilidade em empreendimentos imobiliários residenciais: avaliação dos custos adicionais para o atendimento dos requisitos de certificação ambiental [Sustainability in residential real estate developments: evaluation of additional costs for compliance with the requirements of environmental certification]. Thesis, Masters. Escola Politécnica da Universidade de São Paulo. Departamento de Engenharia de Construção Civil e Urbana. São Paulo, 2013.

SERNA, Sandra C. B.; MOTTA, Mara L. A. Caixa Econômica Federal. Electronic publication [personal message]. Messages received by $<\mathrm{mmb} @$ puc-rio.br $>$ on Feb. 10 and 14. 2017. 